Report No. BMI-1327

UC-25 Metallurgy and Ceramics (TID-4500, 14th Ed.)

Contract No. W-7405-eng-92

THE PREPARATION AND PROPERTIES OF THREE REFRACTORY BERYLLIDES

by

Walston Chubb

Ronald F. Dickerson

March 3, 1959

(Issued September 2, 1959)

BATTELLE MEMORIAL INSTITUTE $505 \mathrm{King}$ Avenue

Columbus 1, Ohio 


\section{DISCLAIMER}

This report was prepared as an account of work sponsored by an agency of the United States Government. Neither the United States Government nor any agency Thereof, nor any of their employees, makes any warranty, express or implied, or assumes any legal liability or responsibility for the accuracy, completeness, or usefulness of any information, apparatus, product, or process disclosed, or represents that its use would not infringe privately owned rights. Reference herein to any specific commercial product, process, or service by trade name, trademark, manufacturer, or otherwise does not necessarily constitute or imply its endorsement, recommendation, or favoring by the United States Government or any agency thereof. The views and opinions of authors expressed herein do not necessarily state or reflect those of the United States Government or any agency thereof. 


\section{DISCLAIMER}

Portions of this document may be illegible in electronic image products. Images are produced from the best available original document. 


\section{TABLE OF CONTENTS}

$\underline{\text { Page }}$

\section{ABSTRACT}

INTRODUCTION

EXPERIMENTAL WORI

\section{Melting Studies}

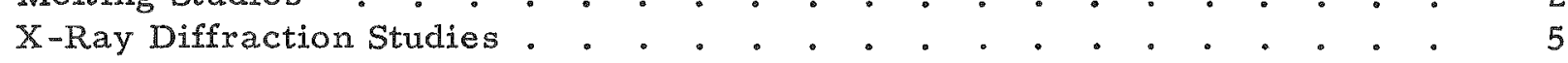

Metallography and Hardness . . . . . . . . . . . . . . . . 10

Oxidation Tests . . . . . . . . . . . . . . . . . . . . 10

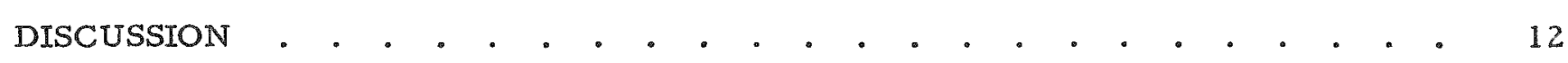

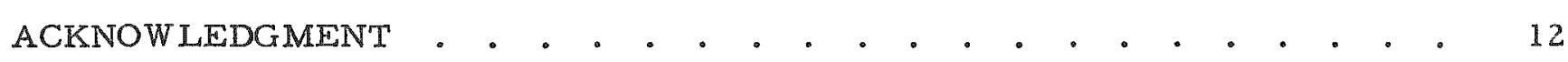

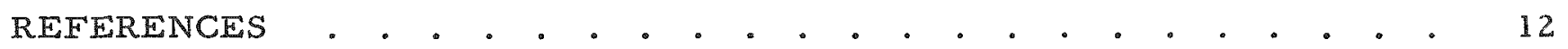




\title{
THE PREPARATION AND PROPERTIES OF THREE REFRACTORY BERYLLIDES
}

\author{
Walston Chubb and Ronald F. Dickerson
}

\begin{abstract}
The beryllium compounds $\mathrm{NbBe_{12 }}, \mathrm{YB} \mathrm{e}_{13}$, and $\mathrm{ZrB} \mathrm{e}_{12}$ were prepared by are melting. Some beryllium was lost in this operation but sound ingots were obtained. The hardness, density, metallographic structure, X-ray structure, and oxidation resistance in air of each ingot were determined.
\end{abstract}

The zirconium compound apparently had a tetragonal structure corresponding

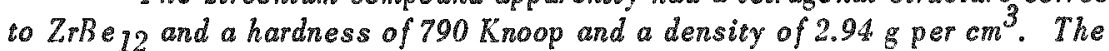
yitrium compound had a cubic structure corresponding to $Y B e_{13}$ and a hardness of 870 Knoop and a density of $2.57 \mathrm{~g}$ per $\mathrm{cm}^{3}$. The niobium compound had a tetragonal structure corresponding to $\mathrm{NbBe} 12$ and a hardness of 1100 Knoop and a density of

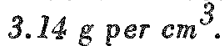

The zirconium alloy was most difficult to prepare and crumbled at $700 \mathrm{C}$ during oxidation testing. The niobium and yttrium alloys were both relatively easy to prepare and both were highly resistant to oxidation at $1300 \mathrm{C}$. The niobium alloy had the mosi satisfactory behavior in all respects and appears mosi promising for further development.

\section{INTRODUCTION}

Beryllium is an extremely oxidation-resistant metal, and it may reasonably be expected that some beryllium-rich alloys and compounds share this oxidation resistance to some degree. In addition, beryllium-rich alloys and intermetallic compounds may be expected to have beryllium densities and thermal conductivities near that of beryllium. A few beryllium-rich intermetallic compounds are also known to have melting points above that of pure beryllium. In this research only the more refractory beryllium-rich compounds having low thermal neutron capture cross sections, having high boiling points, and containing more than 91 a/o beryllium were considered.

A survey of the literature on beryllium compounds $(1-13)$ disclosed two distinct types of beryllium compounds containing more than 91 a/o beryllium. The first type has the general formula $\mathrm{MBe}_{13}$ and a face-centered-cubic structure of the $\mathrm{D} 2_{3}$ type $(\mathrm{NaZn} 13)$. This type of beryllium compound is formed only with the elements of Groups 2A and 3A of the periodic chart, including the lanthanide and actinide series elements. According to the literature, zirconium may also form a compound, $\mathrm{ZrBe} 13$; but, if so, this is the only such compound found outside of Groups $2 \mathrm{~A}$ and $3 \mathrm{~A}$. The second type of beryllium compound containing more than 91 a/o beryllium has the general formula $\mathrm{MBe}_{12}$, and usually has a body-centered-tetragonal structure of the $\mathrm{ThMn}_{12}$ and $\mathrm{NbBe}_{12}$ type. This type of beryllium compound is formed with many of the elements of Groups 4A, 5A, 6A, 7A, and 8 of the periodic chart.

(1) References at end. 
The literature mentions six beryllium-rich compounds of elements having low thermal-neutron capture cross sections. These compounds are $\mathrm{CaBe}_{13}, \mathrm{CeBe}_{13}$, $\mathrm{MgBe}_{13}, \mathrm{NbBe}_{12}, \mathrm{YBe}_{13}$, and $\mathrm{ZrBe}_{13}$. Calcium, cerium, and magnesium have low boiling points relative to the melting point of beryllium; and, therefore, the se compounds probably cannot be prepared by standard melting techniques. The preparation and properties of the compounds $\mathrm{NbBe}_{12}, \mathrm{YBe}_{13}$, and $\mathrm{ZrBe}_{13}$ is the subject of this investigation.

\section{EXPERIMENTAL WORK}

\section{Melting Studies}

The materials used for these studies were sintered beryllium (about 98 per cent metallic beryllium), sintered niobium metal (over 99 per cent niobium), cast and hotrolled yttrium metal (over 99 per cent yttrium), and cast and wrought iodide zirconium (over 99.5 per cent zirconium). The major impurity in the beryllium, yttrium, and zirconium was oxygen. The major impurity in the niobium was zirconium.

Charges weighing $25 \mathrm{~g}$ were melted in an inert-electrode flip-type arc-melting furnace which does not need to be opened to turn the ingot over for remelting. Melting was accomplished using $2 / 3$ atm absolute pressure of helium gas in the furnace. The zirconium-beryllium alloy was melted at 25 to $35 \mathrm{v}$ and 400 to $600 \mathrm{amp}$ with considerable difficulty. The first four melting operations resulted in a porous ball of clinker which split into several fragments on cooling. On subsequent melts the porosity gradually decreased until on the eighth melt the coherent button shown in Figure 1 was obtained. Considerable beryllium was volatilized and condensed on the inner walls of the melting furnace during the course of the eight melting operations. The ingot shown in Figure 1 analyzed $53 \mathrm{w} / 0$ zirconium and weighed $20 \mathrm{~g}$, whereas the charge weighed $25 \mathrm{~g}$ and contained only $43 \mathrm{w} / 0$ zirconium. The refractory behavior of this alloy during melting suggested that it had a melting point well above the melting points of the constituent elements, perhaps $2000 \mathrm{C} \pm 300 \mathrm{C}$.

Two ingots of yttrium-beryllium alloys were prepared. The first ingot was melted at 25 to $35 \mathrm{v}$ and 400 to $600 \mathrm{amp}$. Like the zirconium alloy, the yttrium alloy formed a porous ball on the first meltdown, but some solid metal formed around the circumference of the porous mass even on the first melt. After three melts, the melting behavior of the yttrium-beryllium alloy became quiet, and gas evolution was confined to the final stages of solidification. After six melts the button shown in Figure 2 was obtained. Some beryllium was volatilized during the melting of this ingot. It weighed $23 \mathrm{~g}$ and analyzed $46 \mathrm{w} / 0$ yttrium, as compared with a charge of $25 \mathrm{~g}$ containing only $43 \mathrm{w} / 0$ yttrium. The melting behavior of this ingot suggested that it had a melting point near or only slightly above the melting points of the constituent elements, perhaps $1600 \mathrm{C} \pm 300 \mathrm{C}$. The favorable melting behavior of this first ingot suggested that better analytical results could be obtained, and a second ingot was prepared. A portion of the first ingot was used as a starter charge in the second ingot, and as a result the second ingot melted with very little gas evolution. Unfortunately for the analytical results, an 


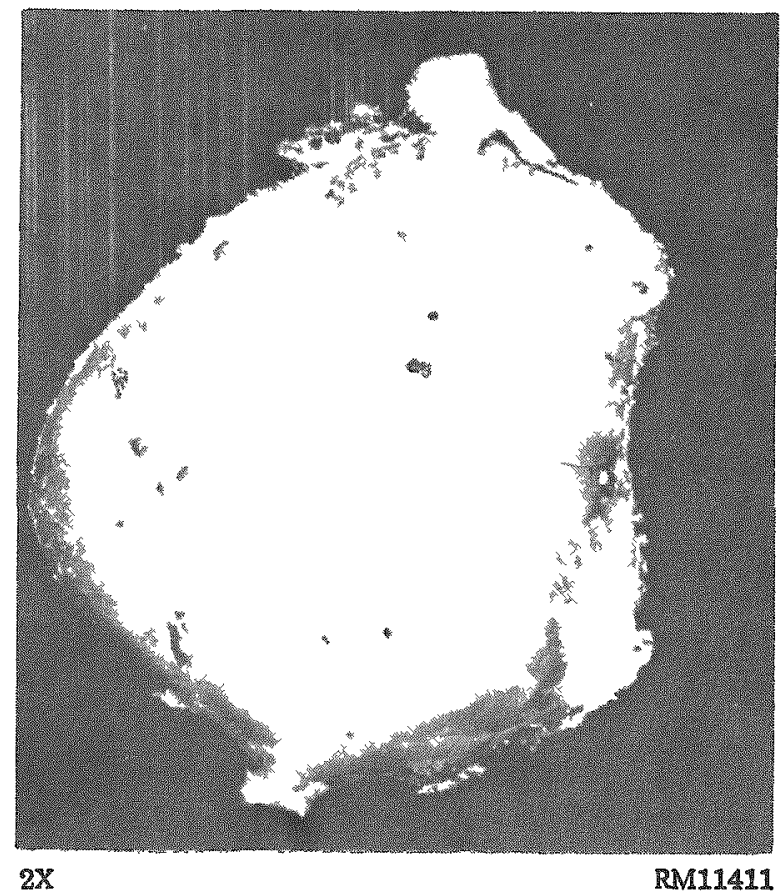

FIGURE 1. ARC-MELTED INGOT OF THE $53 \mathrm{~W} / \mathrm{O}$ ZIRCONIUM 47 W/O BERYLLIUM ALLOY Photograph shows the ingot after the eighth melt. Original charge contained $43 \mathrm{w} / \mathrm{o}$ zirconuun.

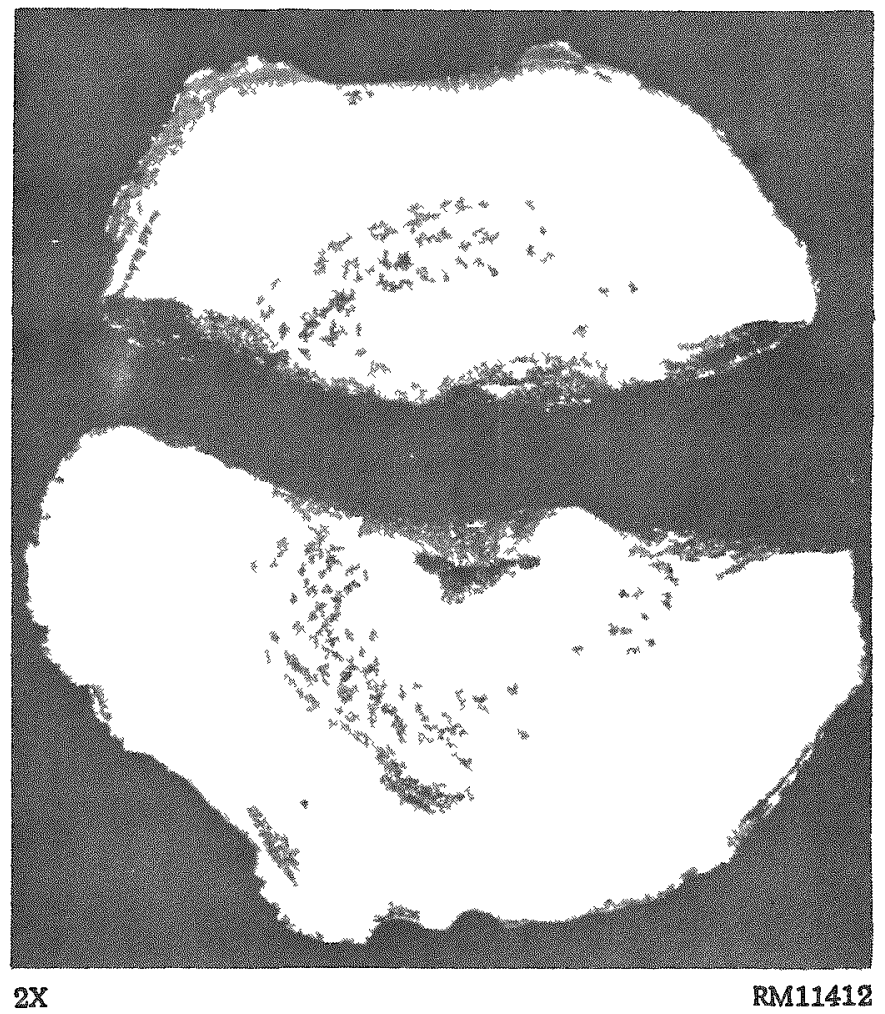

FIGURE 2. ARC-MELTED INGOT OF THE $46 \mathrm{w} / \mathrm{O}$ YTTRIUM $=54 \mathrm{w} / \mathrm{O}$ BERYLLIUM ALLOY

Photograph shows the ingot after the sixth remelt. Original charge of yttrum was $43 \mathrm{w} / \mathrm{o}$. 
attempt was made to cast this second ingot into the form of a slab by the inert arc dropcasting technique. A tenacious film on the surface of the molten metal frustrated all attempts to cause the metal to flow into the mold opening, and the mold became overheated in the attempt, and alloyed with the button to a limited extent. This accident occurred during the eighth melt of this ingot and only $22 \mathrm{~g}$ of the oxiginal $25-\mathrm{g}$ charge were recovered. This material contained $49 \mathrm{w} / 0$ yttrium and $0.4 \mathrm{w} / 0$ copper.

An ingot of niobium-beryllium alloy was melted at 25 to $35 \mathrm{v}$ and approximately $400 \mathrm{amp}$. No puffines or gas evolution was observed during the melting of this alloy, although considerable beryllium was vaporized and condensed on the walls of the melting furnace. It is believed that much of this beryllium was evolved during the first few remelts before all of the niobium was dissolved. Prealloying the niobium with perhaps $10 \mathrm{w} / 0$ beryllium might reduce this tendency to volatilize beryllium. The niobiumberyllium ingot was recovered as a sound button containing no serious defects after six melts. However, two additional remelts were made in an attempt to make a drop casting of this alloy. The product of the eighth melt was cracked into five pieces, as shown in Figure 3. The photograph shows the bottom of the ingot, and the slight mound running from left center to lower right across the button illustrates the extent to which the molten metal entered the slab mold. This ingot weighed $22 \mathrm{~g}$ and analyzed $52 \mathrm{w} / 0$ niobium, as compared to a charge weight of $25 \mathrm{~g}$ containing $46 \mathrm{w} / 0$ niobium. The relative ease with which this alloy melted suggested that it had a melting point near that of beryllium, perhaps $1500 \mathrm{C} \pm 300 \mathrm{C}$.

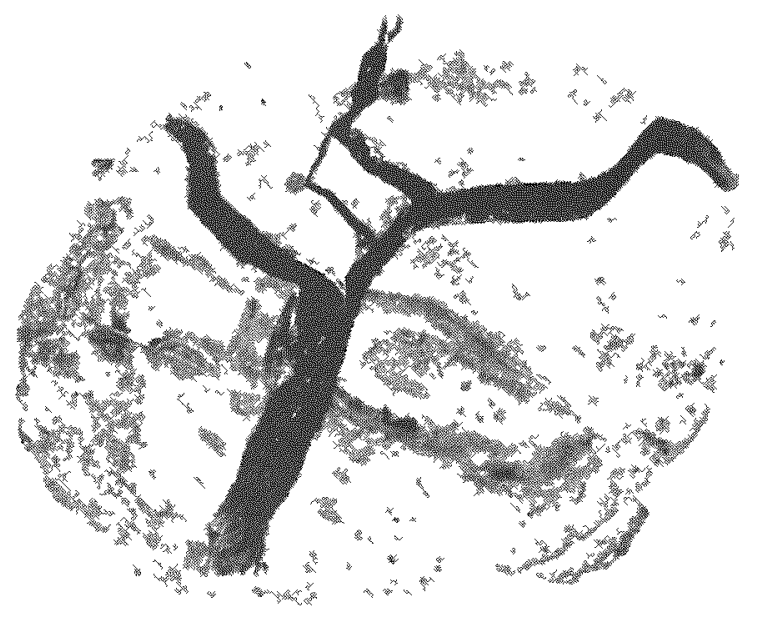

$2 \mathrm{X}$

RMI1643

FIGURE 3. ARC-MELIED INGOT OE THE $52 \mathrm{w} / 0$ NIOBIUM-48 w/o BERYLLIUM ALLOY

Photograph shows the bottom of the ingot following an attempt to make a drop casting in a slab mold. The original charge contained $46 \mathrm{w} / 0$ niobium. The ingot is shown after the eighth nolt. 
According to the analyses obtained above, only beryllium was lost from the charges during arc melting. This metal was vaporized during melting and condensed on the walls of the furnace as an extremely fine (apparently amorphous) metal powder. The deposit was pyrophoric and tended to smear like graphite during cleanup so as to present a considerable potential fire and consequent health hazard. A furnace designed to melt beryllium alloys exclusively could be operated in an inert atmosphere so as to eliminate the fire hazard, and most of the vapor-deposited beryllium could be collected and reused. Under such conditions the health hazard would be negligible.

Density measurements were obtained on fragments of each ingot by weighing the fragments by means of an analytical balance, first in air and then in water. The densities were as follows: beryllium-53 w/0 zirconium, $2.94 \mathrm{~g}$ pex $\mathrm{cm}^{3}$; beryllium-46 w/0 yttrium, $2.57 \mathrm{~g}$ per $\mathrm{cm}^{3}$; beryllium $-52 \mathrm{w} / 0$ niobium, $3.14 \mathrm{~g}$ per $\mathrm{cm}^{3}$.

\section{$\underline{X-R a y ~ D i f f r a c t i o n ~ S t u d i e s ~}$}

$\mathrm{X}$-ray diffraction patterns were obtained on powdered samples of each alloy (except the copper-contaminated yttrium alloy) using a Debye-Scherrer camera and manganese-filtered iron radiation. The powdered samples were not homogenized or heat treated in any way, so that the patterns obtained represent the alloys in their ascast condition. This procedure was intended to and, in some cases, undoubtedly has caused the suppression of equilibrium phases which form by sluggish reactions at low temperatures. It is believed that the phases which have been detected are those phases in each system which have congruent melting points; $i . e .$, their melting points coincide with the liquidus.

The zirconium alloy produced a pattern containing at least two crystal structures. One of these was the body-centered-tetragonal structure found for the isotypes $\mathrm{ThMn}_{12}$ and $\mathrm{NbBe}_{12}$. The compound producing this $\mathrm{X}$-ray pattern in this alloy is presumed to be $\mathrm{ZrBe}_{12}$. The pattern and lattice parameters associated with this compound are shown in Table 1. The second structure was neither the face-centered-cubic $\left(\mathrm{NaZn}_{13}\right)$ type structure nor the hexagonal $\left(\mathrm{AlB}_{2}\right)$ type structure(14), and it must be concluded that this unknown pattern derives from one of the compounds intermediate to $\mathrm{ZrBe}_{12}$ and $\mathrm{ZrBe}_{2}$.

The yttrium alloy produced a pattern showing one predominant crystal structure. This structure was face-centered cubic of the $\mathrm{NaZn}_{13}\left(\mathrm{D}_{3}\right)$ type; and the compound producing this $X$-ray pattern is presumed to be $Y \mathrm{Ye}_{13}$. The pattern and lattice parameter associated with this compound are shown in Table 2.

The niobium alloy produced a pattern showing one predominant crystal structure. This was the body-centered tetragonal structure found for the isotypes $\mathrm{ThMn}_{12}$ and $\mathrm{NbBe}_{12}$. The compound producing this $\mathrm{X}$-xay pattern in this alloy is presumed to be $\mathrm{NbBe} 12$. The pattern and lattice parameters associated with this compound are shown in Table 3. It should be noted that this pattern and the pattern produced by the zirconium compound do not index precisely on a tetragonal net. This finding suggests that perhaps the structure has been incorrectly described as tetragonal or that perhaps impurities or nonequilibrium conditions have distorted the structure. The compounds $\mathrm{NbBe}_{12}$ and $\mathrm{ZrBe}_{12}$ found in these alloys are certainly isostructural, however. 
TABLE 1. STANDARD X-RAY POWDER PATTERN OF ZrBe 12

\begin{tabular}{llll}
\hline $\mathrm{d}$ & $\mathrm{I}_{\mathrm{O}}(\mathrm{a})$ & $\mathrm{d}$ & $\mathrm{I}_{\mathrm{O}}$ \\
\hline 3.76 & 0.8 & 1.318 & 0.5 \\
3.13 & 0.3 & 1.260 & 0.15 \\
2.63 & 1.0 & 1.190 & 0.5 \\
2.18 & 0.5 & 1.164 & 0.5 \\
1.88 & 0.8 & 1.147 & 0.1 (diff.) \\
1.795 & 0.2 & 1.126 & 0.6 \\
1.68 & 0.3 & 1.087 & 0.4 \\
1.65 & 0.3 & 1.067 & 0.6 \\
$1.46(?)$ & 0.05 & 1.045 & 0.5 \\
1.425 & 0.3 & 1.037 & 0.4 \\
1.405 & 0.4 & 1.027 & 0.3 \\
$1.39(?)$ & 0.1 & 1.0065 & 0.8 \\
\hline \hline
\end{tabular}

Body-centered tetragonal: $a_{O}=7.48 \pm 0.03 \mathrm{~A}, c_{O}=4.35 \pm 0.03 \mathrm{~A}$.

(a) An intensity of 1.0 indicates a line of very strong or high intensity in the pattern: "diff." indicates a diffuse line. 
TABLE 2. STANDARD X-RAY POWDER PATTERN OF YBe 13

\begin{tabular}{cccc}
\hline $\mathrm{d}$ & $\mathrm{I}_{0}(\mathrm{a})$ & $\mathrm{d}$ & $\mathrm{I}_{0}$ \\
\hline 5.12 & 0.8 & 1.37 & 0.8 \\
3.62 & 1.0 & 1.280 & 0.1 \\
2.96 & 0.6 & 1.242 & 0.8 \\
2.56 & 0.4 & 1.204 & 0.6 \\
2.29 & 1.0 & 1.172 & 0.5 \\
2.09 & 1.0 & 1.144 & 0.4 \\
1.81 & 0.2 & 1.117 & 0.6 \\
1.70 & 0.5 & 1.091 & 0.5 \\
1.61 & 0.7 & 1.045 & 0.8 \\
1.54 & 0.5 & 1.024 & 0.3 \\
1.48 & 0.4 & 1.004 & 1.0 \\
1.42 & 0.6 & 0.985 & 0.8 \\
\hline
\end{tabular}

Face-centered cubic: $a=10.237 \pm 0.003 \mathrm{~A}$.

(a) An intensity of 1.0 indicates a line of very strong or high intensity in the pattern. 
TABLE 3. STANDARD X-RAY POWDER PATTERN OF NbBe 12

\begin{tabular}{|c|c|c|c|}
\hline $\mathrm{d}$ & $I_{0}(a)$ & $\mathrm{d}$ & $I_{0}$ \\
\hline 3.67 & 0.8 & 1. 190 & 0.05 \\
\hline 2.59 & 1.0 & 1. 164 & 0.6 \\
\hline 2.32 & 0.1 & 1.143 & 0.3 (diff.) \\
\hline 2.13 & 0.5 & 1.103 & 0.5 \\
\hline 1.98 & 0.05 & 1.085 & 0.05 (diff.) \\
\hline 1.84 & 1.0 & 1.067 & 0.5 \\
\hline 1.73 & 0.05 & 1.059 & 0.1 \\
\hline 1.64 & 0.3 & 1.048 & 0.5 (diff.) \\
\hline 1.61 & 0.3 & 1.037 & 0.05 \\
\hline 1.43 & 0.1 & 1.025 & 0.4 \\
\hline 1.392 & 0.4 & 1.024 & 0.5 \\
\hline 1.372 & 0.5 & 1.0185 & 0.5 \\
\hline 1.301 & 0.6 & 1.008 & 0.08 \\
\hline 1.288 & 0.5 & 0.9865 & 0.6 \\
\hline 1. 230 & 0.25 & & \\
\hline
\end{tabular}

Body-centered tetragonal: $a_{0}=7.34 \pm 0.02 \mathrm{~A}, c_{0}=4.26 \pm 0.02 \mathrm{~A}$.

(a) An intensity of 1.0 indicates a line of very strong or high intensity in the pattern; diffuse lines are indicated by "diff.". 


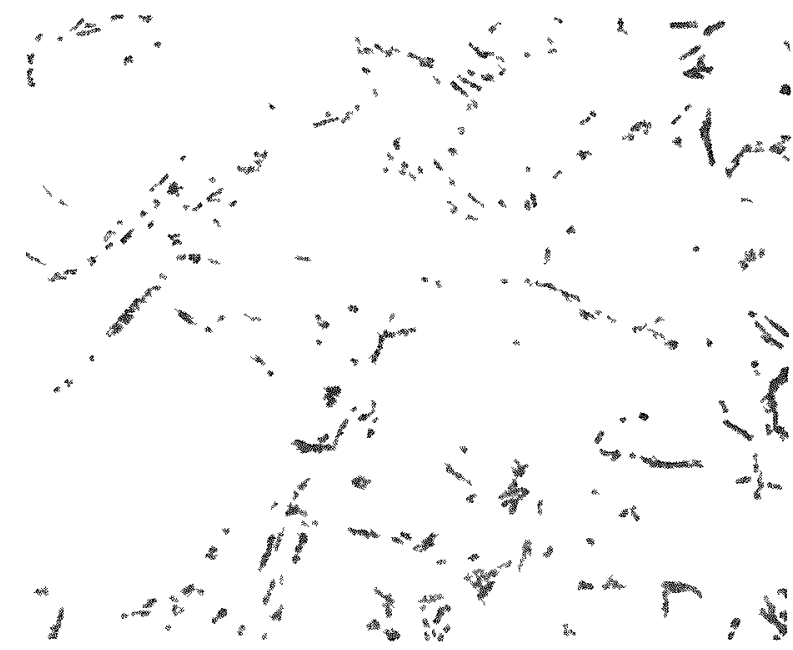

$250 \times$ RM11431

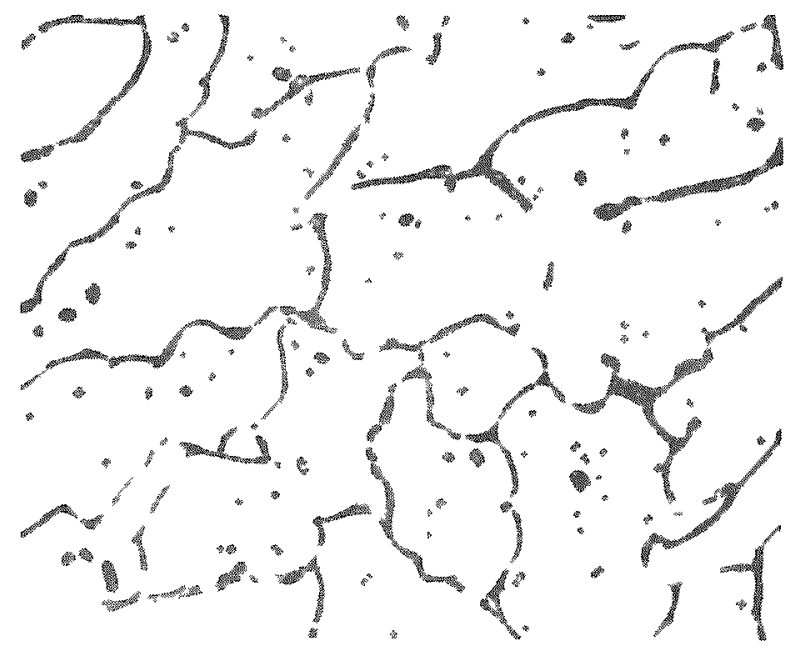

$250 x$
RM11430

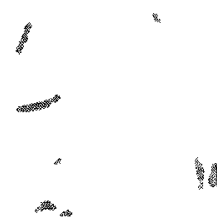

新

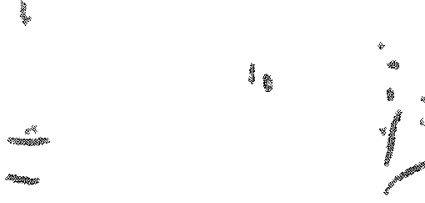

FIGURE 4. AS॰CAST STRUCTURE OF THE $53 \mathrm{w} / 0$ ZIRCONIUM 47 W/O BERYLLIUM ALLOY

Major phase present is believed to be ZrBe 12. Knoop hardness: $790 \mathrm{~kg}$ per $\mathrm{mm}^{2}$.
FIGURE 5. AS CAST STRUCTURE OF THE $46 \mathrm{~W} / 0$ YTTRIUM-54 W/O BERYLLIUM ALLOX

Major phase present is YBe13. Grain boundary phase is probably yttrium. Knoop hardness: $870 \mathrm{~kg}$ per $\mathrm{mm}^{2}$.
FIGURE 6. AS CAST STRUCTURE OF THE $52 \mathrm{w} / \mathrm{O}$ NIOBIUM-48 $\mathrm{w} / \mathrm{O}$ BERTLLIUM ALLOY

Major phase present is $\mathrm{NbBe}_{12}$. The secondary phase is also a compound, possibly NbBe2. Knoop hardness: $1100 \mathrm{~kg}$ per $\mathrm{mm}^{2}$. 
Metallography and Hardness

Samples of each alloy in the as-cast condition were prepared for metallographic examination by grinding and polishing by standard techniques. Etching was accomplished using a solution consisting of lactic acid-50 volume per cent nitric acid, plus 5 drops of hydrofluoric acid per $100 \mathrm{~cm}^{3}$ of solution.

Photomicrographs of a typical section of each of the alloys are shown in Figures 4 , 5, and 6. In no case does the secondary constituent present in each of these alloys appear to amount to moxe than 5 volume per cent of the alloy. The photomicrograph of the zirconium alloy shows many discontinuous hairline cracks which undoubtedly contributed to its rapid disintegration during subsequent oxidation tests. The major phase shown in Figure 4 is believed to be the beryllium-rich compound (probably $\mathrm{ZrBe}_{12}$ ). The Knoop hardness $\left(500-\mathrm{g}\right.$ load) of this zirconium alloy was $790 \mathrm{~kg}$ per $\mathrm{mm}^{2}$. The yttrium alloy shows a rapid-etching grain-boundary phase, and, since there is probably only one compound, $\mathrm{YBe}_{13}$, containing $43 \mathrm{w} / 0$ yttrium, in this system and the alloy contains $46 \mathrm{w} / \mathrm{o}$ yttrium, this grain-boundary phase probably is largely yttrium metal. The matrix is presumed to be $\mathrm{YBe}_{13}$, and this had a $K$ noop hardness of $870 \mathrm{~kg}$ per $\mathrm{mm}^{2}$. The niobium alloy, Figure 6 , shows a few cracks which appear to be associated with the secondary phase. The lack of penetration of these cracks into the matrix suggests that the second phase is much more brittle than the primary phase. The major phase shown in Figure 6 is presumed to be $\mathrm{NbBe}_{12}$. By analogy with the iron-beryllium system, the secondary phase in this alloy is also an intermetallic compound, possibly NbBe 2 . This specimen had a Knoop hardness of $1100 \mathrm{~kg}$ per $\mathrm{mm}^{2}$. None of the alloys showed any crushing or cracking under the Knoop indenter at the 500-g load. This behavior suggests that the alloys are not totally brittle in compression.

\section{Oxidation Tests}

Small, apparently solid and uncracked chunks of the as-cast ingots were placed in separate porcelain crucibles. These were covered and heated to successively higher temperatures in air. After $1 \mathrm{hr}$ at each temperature, the crucibles were cooled, weighed, and then reheated to the next higher temperature in steps of $200 \mathrm{C}$ starting at $300 \mathrm{C}$. The results of these tests are shown in Table 4. It is quite evident from these data that the niobium-beryllium alloy and the yttrium-beryllium alloy are very resistant to oxidation at temperatures up to $1300 \mathrm{C}$. The niobium alloy appears to be slightly more resistant to oxidation at $1300 \mathrm{C}$ than the yttrium alloy. The zirconium alloy is relatively soft and friable, and because of its friability, it does not appear to have satisfactory oxidation resistance at temperatures ove $700 \mathrm{C}$. The friability of the zirconium alloy is probably associated with the cracks observed in its microstructure. 
TABLE 4. OXIDATION TESTS OF BERYLLIUM-RICH ALLOYS

\begin{tabular}{|c|c|c|c|c|c|}
\hline \multirow{2}{*}{$\begin{array}{c}\text { Alloy Composition } \\
\text { (Balance Beryllium), } \\
w / 0 \\
\end{array}$} & \multirow{2}{*}{$\begin{array}{c}\text { Initial Sample } \\
\text { Weight, } g\end{array}$} & \multirow{2}{*}{$\begin{array}{l}\text { Temperature } \\
\text { of } 1-\mathrm{Hr} \text { Test, } \\
\mathrm{C}\end{array}$} & \multicolumn{2}{|c|}{$\begin{array}{c}\text { Total } \\
\text { Weight Gain }\end{array}$} & \multirow[b]{2}{*}{ Appearance } \\
\hline & & & $\mathrm{G}$ & Per Cent & \\
\hline \multirow[t]{3}{*}{$53 \mathrm{Zr}$} & 1.6318 & 500 & 0 & 0 & Metallic \\
\hline & & 700 & 0.0930 & 5.7 & Some oxide; specimen crumbled \\
\hline & & 900 & 0.2616 & 16 & Specimen reduced to powder \\
\hline \multirow{5}{*}{$46 \mathrm{Y}$} & 0.4673 & 500 & 0.0001 & 0.02 & Metallic \\
\hline & & 700 & 0.0005 & 0.1 & Metallic \\
\hline & & 900 & 0.0019 & 0.4 & Metallic \\
\hline & & 1100 & 0.0049 & 1.0 & Slight oxide visible \\
\hline & & 1300 & 0.0166 & 3.6 & Flaking oxide over sound metal \\
\hline \multirow[t]{5}{*}{$49 \mathrm{Y}-0.4 \mathrm{Cu}$} & 0.9697 & 500 & 0.0009 & 0.09 & Metallic \\
\hline & & 700 & 0.0013 & 0.13 & Metallic \\
\hline & & 900 & 0.0075 & 0.8 & Slight oxide visible \\
\hline & & 1100 & 0.0295 & 3.0 & Oxide visible \\
\hline & & 1300 & 0.0915 & 9.4 & Adherent oxide; specimen fragmented \\
\hline \multirow[t]{5}{*}{$52 \mathrm{Nb}$} & 1.5897 & 500 & 0.0008 & 0.05 & Metallic \\
\hline & & 700 & -- & -- & Metallic \\
\hline & & 900 & 0.0055 & 0.35 & Metallic \\
\hline & & 1100 & 0.0083 & 0.52 & Metallic \\
\hline & & 1300 & 0.0149 & 0.94 & Metallic; flaking oxide \\
\hline
\end{tabular}




\section{DISCUSSION}

The properties of each of the alloys prepared are listed in Table 5. While the $X$-ray data leave some doubt as to the correct crystal structure of the niobium and zirconium compounds $\mathrm{NbBe}_{12}$ and $\mathrm{ZrBe}_{12}$, it is quite clear that the se compounds are isostructural with $T h M_{12}$ and the other $\mathrm{MBe}_{12}$ compounds and that, if these compounds have been correctly described as body-centered tetragonal, the niobium and zirconium compounds are likewise tetragonal. The zirconium compound can be prepared by arc melting, but it appears that castings prepared by melting may contain microcracks which will prevent the use of such castings at elevated temperatures.

Both the niobium alloy and the yttrium alloy demonstrated good behavior during melting, but the niobium alloy had the lowest rate of oxidation in air at $1300 \mathrm{C}$. The data obtained suggest that beryllium-yttrium alloys and beryllium-niobium alloys should be investigated in greater detail.

Hypothetical phase diagrams for the systems investigated are shown in Figures 7 , 8, and 9. These diagrams have been drawn by taking into consideration all the data. available from the literature and from this investigation. The resultant diagrams are believed to be consistent with almost all of the data available.

\section{ACKNOWLEDGMENT}

The authors are indebted to J. Robert Doig, Jr., of Battelle for the X-ray data and structural calculations included in this report.

\section{REFERENCES}

(1) Von Batchelder, F. W., and Raeuchle, R. F., "The Structure of a New Series of MBe 12 Compounds", Acta Cryst., 10, 648 (October, 1957).

(2) Raeuchle, R. F., and von Batchelder, F. W., "The Structure of MoBe 12 ", Acta Cryst., 8, 691 (1955). See also Reference (13).

(3) Gordon, S. G., McGurty, J. A., Klein, G. E., and Koshuba, W. J., "Intermetallic Compounds in the System Molybdenum-Beryllium", Trans. AIME, 191, 637 (August, 1951).

(4) Hansner, H. H., and Kalish, H. S., "Preliminary Investigation of the ZirconiumBeryllium System by Powder Metallurgy Methods", Trans. AIME, 188, 59 (January, 1950); also see Discussion, p 1369. 
TABLE 5. TABULATED PROPERTIES OF BERYLLIUM ALLOYS

\begin{tabular}{|c|c|c|c|}
\hline & $\begin{array}{c}\text { Beryllium-53 w/o } \\
\text { Zirconium } \\
\end{array}$ & $\begin{array}{c}\text { Beryllium }-46 \mathrm{w} / \mathrm{o} \\
\text { Yttrium }\end{array}$ & $\begin{array}{c}\text { Beryllium }-52 \mathrm{w} / \mathrm{o} \\
\text { Niobium } \\
\end{array}$ \\
\hline Major Constituent & $\mathrm{ZrBe}_{12}$ & $\mathrm{YBe}_{13}$ & $\mathrm{NbBe}_{12}$ \\
\hline $\begin{array}{l}\text { Minor Constituent, } \\
\text { volume per cent }\end{array}$ & $\sim 3$ & $\sim 5 \mathrm{Y}$ & $\sim 5 \mathrm{NbBe}_{2}(?)$ \\
\hline Approximate Melting Point, C & 2000 & 1600 & 1500 \\
\hline Density, g per $\mathrm{cm}^{3}$ & 2.94 & 2.57 & 3.14 \\
\hline $\begin{array}{l}\text { Knoop Hardness }(500-\mathrm{G} \text { Load), } \\
\mathrm{kg} \text { per } \mathrm{mm}^{2}\end{array}$ & 790 & 870 & 1100 \\
\hline Oxidation Behavior in Air & Crumbled at $700 \mathrm{C}$ & Good at $1300 \mathrm{C}$ & Excellent at $1300 \mathrm{C}$ \\
\hline Crystallographic Isotype & $\operatorname{ThMn}_{12}$ & $\mathrm{NaZn}_{13}$ & $\operatorname{ThMn}_{12}$ \\
\hline $\begin{array}{l}\text { Crystal Structure } \\
\text { Lattice Constant, A }\end{array}$ & Body-centered tetragonal & Face-centered cubic & Body-centered tetragonal \\
\hline $\begin{array}{l}\mathrm{a} \\
\mathrm{c}\end{array}$ & $\begin{array}{l}7.48 \\
4.35\end{array}$ & $\begin{array}{c}10.237 \\
--\end{array}$ & $\begin{array}{l}7.34 \\
4.26\end{array}$ \\
\hline $\mathrm{X}$-Ray Density, g per $\mathrm{cm}^{3}$ & 2.70 & 2.53 & 2.89 \\
\hline
\end{tabular}




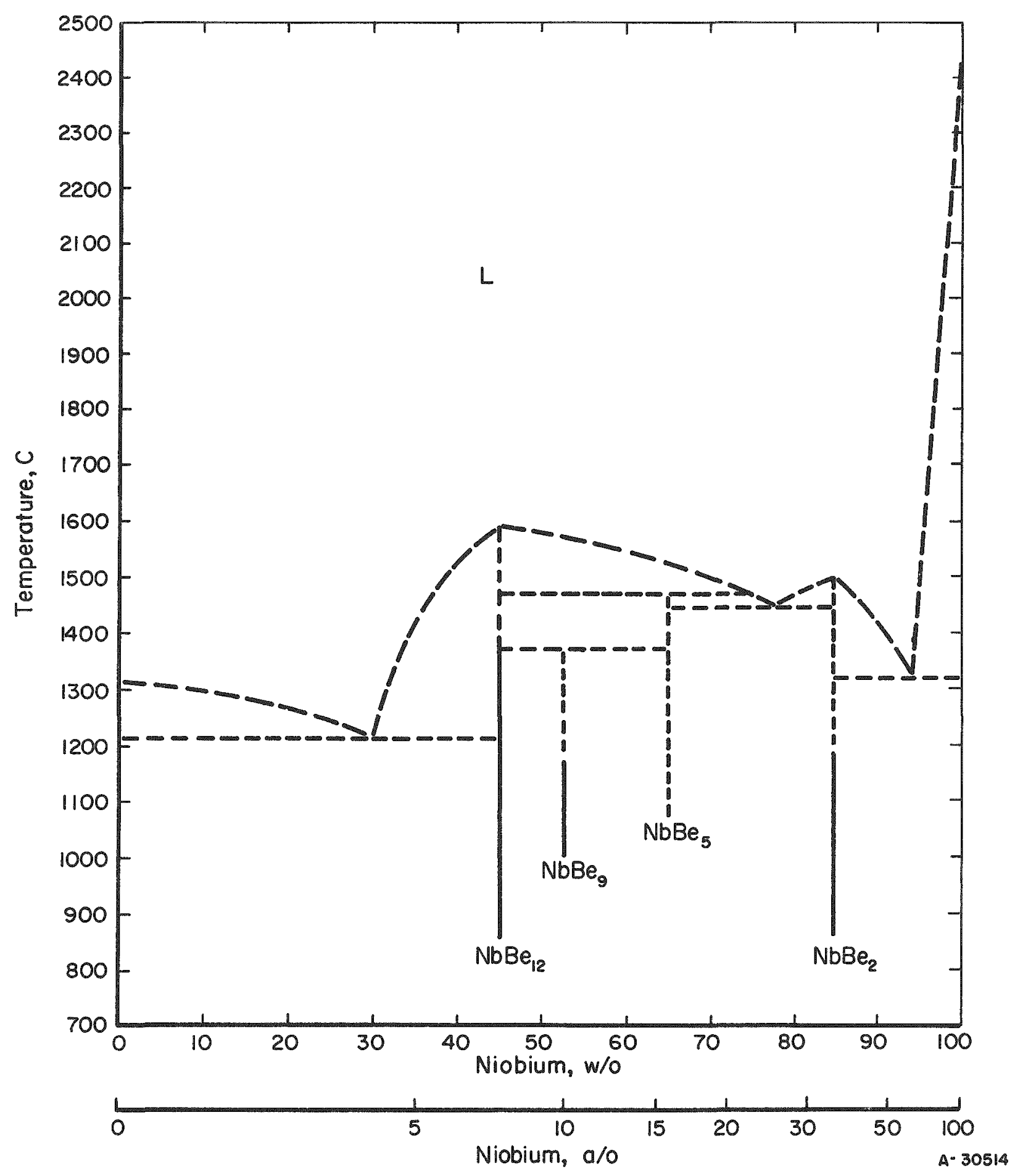

FIGURE 7. HYPOTHETICAL BERYLLIUM-NIOBIUM CONSTITUTION DIAGRAM 


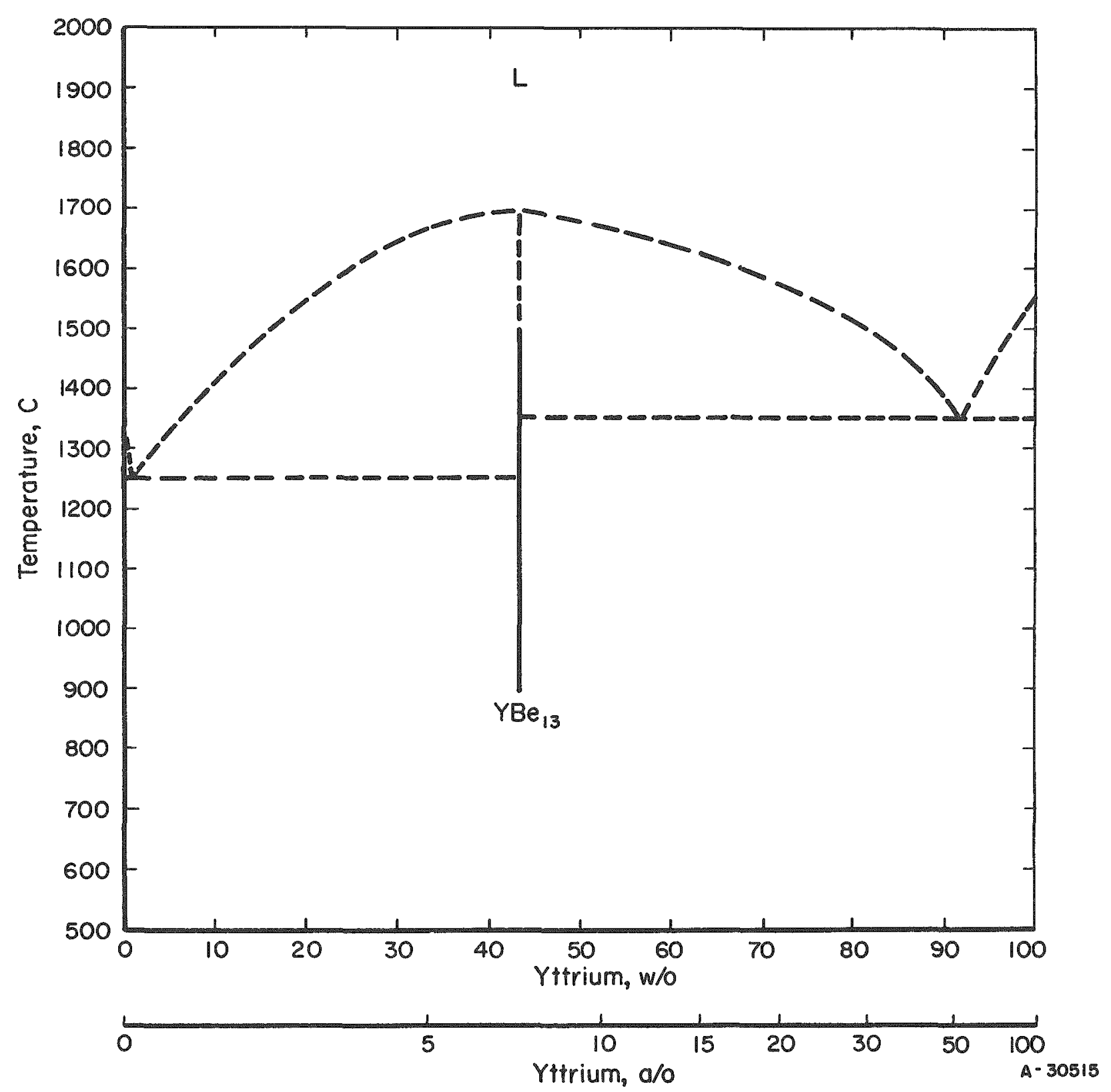

FIGURE 8. HYPOTHETICAL BERYLLIUM-YTTRIUM CONSTITUTION DLAGRAM 


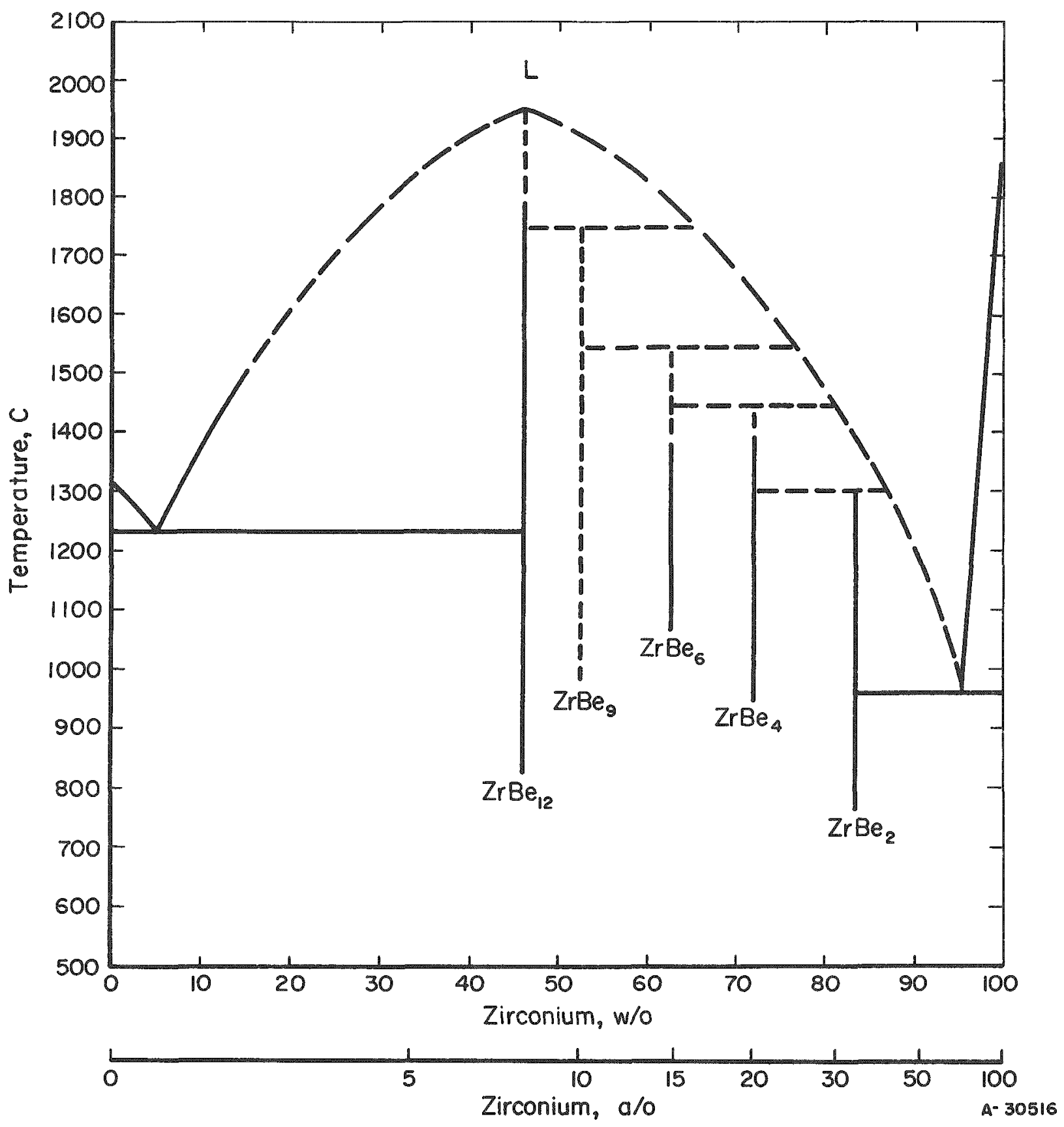

FIGURE 9. HYPOTHETICAL BERYLLIUM-ZIRCONIUM CONSTITUTION DIAGRAM 
(5) McGurty, J.A., Gordon, S. G., Klein, G. F。, and Wizeman, K. M., "Proceedings of the Metallurgy and Materials Information Meeting", TID-5061, p 487 (Apri1, 1951).

(6) Koehler, W. C., Singer, J., and Coffinberry, A. S., "Studies of the MBe 13 Intermetallic Compound", Acta Cryst., 5, 394 (1952).

(7) Baenziger, N. C., and Rundle, R. E., "The MBe 13 Compounds", Acta Cryst., 2. $258(1949)$.

(8) Hansen, M., and Anderko, K., Constitution of Binary Alloys, McGraw-Hill Book Co., New York (1958), pp 287, 291, 294, 298.

(9) Kripiakevich, P.I., and Gladyskevskii, E. I., "Crystal Structure of the Compounds, $\mathrm{CrBe} 12, \mathrm{VBe}_{12}$, and $\mathrm{NbBe}_{12}$ ", Doklady Akad. Nauk. SSSR, 104, 82 (1955).

(10) Baker, T.W., and Williams, J., "The Intermetallic Compounds $\mathrm{MgBe}_{13}$ and $\mathrm{CaBe}_{13}$ ", Acta Cryst., 8, 519 (1955).

(11) Raeuchle, R. F., and Rundle, R. E., "The Structure of TiBe12", Acta Cryst., $\underline{5}, 85$ (1952).

(12) Paine, R. M., and Stonehouse, A. J., "Investigation of Inter metallic Compounds for Very High Temperature Applications", WADC-TR-57-240 (March, 1957). Secret.

(13) Florio, J. V., Rundle, R. E., and Snow, A. I., "The Thorium-Manganese System", Acta Cryst., 5, 449 (1952).

(14) Nielsen, J. W., and Baenziger, N. C., "The Crystal Structure of ZrBeSi and ZrBe $2^{\prime \prime}$, Acta Cryst., 7, 132 (1954).

WC:RFD/ims 